University of Nebraska - Lincoln

DigitalCommons@University of Nebraska - Lincoln

Biological Systems Engineering: Papers and

Publications

Biological Systems Engineering

6-1-2009

\title{
Actual and Reference Evaporative Losses and Surface Coefficients of a Maize Field during Nongrowing (Dormant) Periods
}

Christopher H. Hay

University of Nebraska-Lincoln, chay2@unl.edu

Suat Irmak

University of Nebraska-Lincoln, suat.irmak@unl.edu

Follow this and additional works at: https://digitalcommons.unl.edu/biosysengfacpub

Part of the Biological Engineering Commons

Hay, Christopher H. and Irmak, Suat, "Actual and Reference Evaporative Losses and Surface Coefficients of a Maize Field during Nongrowing (Dormant) Periods" (2009). Biological Systems Engineering: Papers and Publications. 78.

https://digitalcommons.unl.edu/biosysengfacpub/78

This Article is brought to you for free and open access by the Biological Systems Engineering at DigitalCommons@University of Nebraska - Lincoln. It has been accepted for inclusion in Biological Systems Engineering: Papers and Publications by an authorized administrator of DigitalCommons@University of Nebraska Lincoln. 


\title{
Actual and Reference Evaporative Losses and Surface Coefficients of a Maize Field during Nongrowing (Dormant) Periods
}

\author{
Christopher H. Hay, A.M.ASCE ${ }^{1}$ and Suat Irmak, M.ASCE ${ }^{2}$ \\ ${ }^{1}$ Postdoctoral Research Associate, Biological Systems Engineering Department, \\ University of Nebraska-Lincoln, 237 L. W. Chase Hall, Lincoln, NE 68583-0726 (email chay2@unl.edu ) \\ ${ }^{2}$ Associate Professor, Biological Systems Engineering Department, University of Nebraska-Lincoln, \\ 241 L. W. Chase Hall, Lincoln, NE 68583-0726 (Corresponding author - email sirmak2@unl.edu )
}

\begin{abstract}
Effective water resources planning, allocation, management, and use in agroecosystems require accurate quantification of actual evapotranspiration $\left(\mathrm{ET}_{c}\right.$ ) during growing and nongrowing (dormant) periods. Prediction of $\mathrm{ET}_{c}$ for a variety of vegetation surfaces during the growing season has been researched extensively, but relatively little information exists on evaporative losses during nongrowing periods for different surfaces. The objectives of this research were to evaluate $\mathrm{ET}_{c}$ in relation to available energy, precipitation, and grass and alfalfa-reference ET (ET ${ }_{o}$ and $\left.\mathrm{ET}_{r}\right)$ for a maize (Zea mays L.) field and to analyze the dynamics of surface coefficients $\left(K_{c}\right)$ during the nongrowing period (October 15-April 30). The evaporative losses were measured using a Bowen ratio energy balance system (BREBS) on an hourly basis and averaged over $24 \mathrm{~h}$ for three consecutive nongrowing periods: 2004-2005 (Season I), $2005-2006$ (Season II), and 2006-

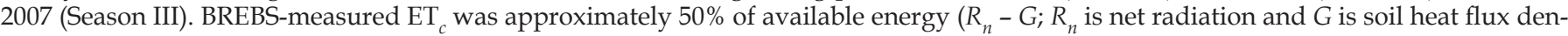
sity) during normal and wet seasons (Seasons I and III) and $41 \%$ of available energy during a dry season (Season II). Cumulative ET ranged from $133 \mathrm{~mm}$ in Season II to $167 \mathrm{~mm}$ in Season III and exceeded precipitation by $21 \%$ during the dry season. The ratio of ET to $_{c}$ precipitation was 0.85 in Season I, 1.21 in Season II, and 0.41 in Season III. ET ${ }_{c}$ was approximately $50 \%$ of $\mathrm{ET}_{o}$ and $36 \%$ of ET $r$ in both Seasons I and III, whereas in Season II, $\mathrm{ET}_{c}$ was $32 \%$ of $\mathrm{ET}_{o}$ and $23 \%$ of $\mathrm{ET}_{r}$. Overall, measured $\mathrm{ET}_{c}$ during the dormant season was generally most strongly correlated with radiation terms, particularly $R_{n^{\prime}}$ albedo, incoming shortwave radiation, and outgoing longwave radiation. Average surface coefficients over the three seasons were 0.44 and 0.33 for grass and alfalfa-reference surfaces, respectively. Using geometric mean $K_{c}$ values to calculate $\mathrm{ET}_{c}$ using a $K_{c} \mathrm{ET}_{\text {ref }}$ approach over the entire nongrowing season yielded adequate predictions with overall root mean square deviations of 0.64 and $0.67 \mathrm{~mm} \mathrm{day}^{-1}$ for $\mathrm{ET}_{o}$ and $\mathrm{ET}_{r^{\prime}}$ respectively. Estimates of ET ${ }_{c}$ using a dual crop coefficient approach were good on a seasonal basis, but performed less well on a daily basis. Regression equations that were developed (accounting for serial autocorrelation in the $\mathrm{ET}_{c}$ and $\mathrm{ET}_{\text {ref }}$ time series) yielded good estimates of $\mathrm{ET}_{c}$. Considering nongrowing period evaporative losses in water budget calculations would enable water regulatory agencies to better account for water use in hydrologic balance calculations over the entire year rather than only for the growing season and to better assess the progression and availability of water resources for the next growing season.
\end{abstract}

Keywords: evapotranspiration, energy, evaporation, soil water, coefficients

\section{Introduction}

As stress on water supplies increases, there are increasing demands for more efficient use of water in agroecosystems. Efficient water use and sound policy decisions on water resources planning, management, and allocation in agroecosystems require an accurate and quantitative understanding of actual evapotranspiration $\left(\mathrm{ET}_{c}\right)$. Research on evapotranspiration from agroecosystems has primarily been conducted only during the growing season, and relatively little research exists on evaporative losses during nongrowing (dormant) periods (Prueger et al. 1998). Precipitation and evaporation during the nongrowing season are important components of the annual hydrologic cycle and impact surface runoff, groundwater recharge, and soil moisture storage for the next growing season (Sauer et al. 1998a,b). Enhanced prediction of nongrowing period evaporative losses would allow water managers to better account for water use in agroecosystems over the entire year. Modeling of the transport of agricultural chemicals that could impact water quality would also benefit from a better understanding of nongrowing period evaporative losses.

Reference ET $\left(\mathrm{ET}_{\text {ref }}\right)$ and crop coefficients $\left(K_{c}\right)$ are commonly used to estimate $\mathrm{ET}_{c}$ during the growing season. Reference ET is calculated using a reference crop of grass or alfalfa $\left(\mathrm{ET}_{o}\right.$ and $\mathrm{ET}_{r}$, respectively). The $\mathrm{ET}_{\text {ref }}$ is then multiplied by an empirically derived crop coefficient $\left(K_{c o}\right.$ and $K_{c r}$ for grass and alfalfa reference crops, respectively) to calculate ET . Standardized $\mathrm{ET}_{\text {ref }}$ equations for computing $\mathrm{ET}_{o}$ and $\mathrm{ET}_{r}$ have recently been recommended by the ASCE EWRI (ASCE-EWRI 2005). However, during the non-growing period, the assumptions of the reference ET equations may be violated much of the time in many regions because of vegetation dormancy, snow cover, and frozen soils (Allen et al. 1998; ASCE-EWRI 2005). A number of factors may lead to unrealistic evapotranspira- 
tion estimates by the combination methods (e.g., ASCE-EWRI Penman-Monteith). In addition to the increased bulk surface resistance, $r_{s^{\prime}}$ the following conditions contribute to unrealistic $\mathrm{ET}_{c}$ estimates during nongrowing periods (Irmak et al. 2008c) (1) the change in the amount of daytime hours to nighttime hours; (2) the greater emphasis of the aerodynamic component of the combination equation relative to the radiation component during periods with lower temperatures and high wind speeds; and (3) unrealistic values of $r_{s}$ at low temperatures. The calculation of net radiation, $R_{n^{\prime}}$ during the growing season assumes an albedo $(\alpha)$ value of 0.23 for a green vegetation surface, which is not realistic during a majority of the nongrowing periods. Experimental knowledge and adequate procedures to estimate soil heat flux (especially for hourly calculations) during freezing conditions are lacking. Thus, the "standardized" reference surface conditions used in the standardized ASCE-PM equation are not met during nongrowing periods, and may result in potentially unrealistic estimates of ET (Irmak et al. 2008c). Furthermore, varying conditions of soil water availability at the soil surface, snow cover, crop residue cover, and weed growth, make the choice of a crop coefficient difficult (Allen et al. 1998).

Despite the difficulties in applying reference ET during nongrowing periods, the standardized reference ET equations may still be useful as an evaporative index (ASCE-EWRI 2005) if robust relationships between the $\mathrm{ET}_{\text {ref }}$ and measured $\mathrm{ET}_{c}$ can be developed. There were three objectives for this study. The first objective was to evaluate nongrowing season evaporative losses in relation to available energy and precipitation of a field covered with maize residue. The second objective was to compare the measured evapotranspiration with values predicted using the ASCE standardized reference evapotranspiration equations and the FAO-56 dual crop coefficient method (Allen et al. 1998). The third objective was to develop methods for predicting nongrowing season $\mathrm{ET}_{c}$ using $\mathrm{ET}_{\text {ref }}$ with crop coefficient and regression modeling approaches.

\section{Methods}

\section{Study Site, Seasons, and Field Instrumentation}

Measurements of the surface energy balance components were made at the South Central Agricultural Laboratory (SCAL), near Clay Center, Neb. $\left[40^{\circ} 34^{\circ} \mathrm{N}, 98^{\circ} \mathrm{W}, 552 \mathrm{~m}\right.$ mean sea level (MSL)]. Detailed descriptions of field experimental procedures, data collection, and Bowen ratio energy balance measurements have been outlined in detail by Irmak and Irmak (2008), Irmak and Mutiibwa (2008), and Irmak et al. (2008b). Some of the basic experimental practices will be described here. The soil at the study site is a Hastings silt loam (fine, montmorillonitic, mesic Udic Argiustoll), which is a welldrained soil on uplands with field capacity of $0.34 \mathrm{~m}^{3} \mathrm{~m}^{-3}$ and permanent wilting point of $0.14 \mathrm{~m}^{3} \mathrm{~m}^{-3}$ (Hammer et al. 1981). Measurements were taken in a 13 ha subsurface drip-irrigated corn (Zea mays L.) field. Three consecutive nongrowing periods were studied: 2004-2005 (Season I), 2005-2006 (Season II), and 2006-2007 (Season III). Since planting and harvest dates varied slightly from year to year, the nongrowing period was defined as October 15-April 30 to maintain consistency of the analyses. Row spacing for the corn was $0.76 \mathrm{~m}$. Corn yields from the previous growing seasons were 18.8, 17.9, and 15.8 $\mathrm{m}^{3} \mathrm{ha}^{-1}$ for Seasons I-III, respectively, and the study field contained postharvest residue from these harvests. The field was maintained as ridge-till during the growing season, but there were no fall tillage operations, so the surface consisted of the decaying corn residue and bare soil. There was no herbicide application to control weeds after harvest, and there was no winter annual weed presence in the field during the nongrowing season. Significant periods of snow cover occurred during January of Season I, late November to mid-December of Season II, and from mid-December to mid-March of Season III.

Surface energy fluxes were measured using a deluxe version of a Bowen ratio energy balance system (BREBS)[Radiation and Energy Balance Systems (REBS), Inc., Bellevue, Wash.], and $\mathrm{ET}_{c}$ was calculated using the Bowen ratio method. The BREBS was installed in the middle of the study field with fetch distances of $260 \mathrm{~m}$ in the north-south direction and $137 \mathrm{~m}$ in the east-west direction. In addition, the surrounding fields were also planted to corn and contained corn residue during the nongrowing periods (Irmak and Irmak 2008). Temperature and relative humidity gradients were measured using two chromel-constantan thermocouple air temperature and relative humidity probes (REBS Models THP04015 and THP04016, respectively) with resolutions of $0.0055^{\circ} \mathrm{C}$ for temperature and $0.033 \%$ for relative humidity. The temperature and humidity probes were installed on a REBS automatic exchange mechanism and were exchanged every 15 min to correct for any bias in the top and bottom exchanger sensors. Incoming and outgoing shortwave radiation were measured simultaneously using a REBS model THRDS7.1 double sided total hemispherical radiometer that was sensitive to wavelengths from 0.25 to $60 \mu \mathrm{m}$. The surface albedo was calculated from these measurements. Net radiation was measured using a REBS Q*7.1 net radiometer that was installed approximately $4.5 \mathrm{~m}$ above the soil surface. Soil heat flux was measured using three REBS HFT-3.1 heat flux plates and three soil thermocouples. Each soil heat flux plate was placed at a depth of 0.08 $\mathrm{m}$ below the soil surface. The REBS STP-1 soil thermocouple probes were installed in close proximity to each soil heat flux plate at depths of $0.02,0.04,0.06,0.08$, and $0.10 \mathrm{~m}$ below the soil surface. Measured soil heat flux values were adjusted for soil temperatures and soil water content as measured using three REBS SMP1R soil moisture probes. One soil moisture probe was installed in close proximity to each soil heat flux plate. Additional sensors included the following: barometric pressure was measured using a Model 276 barometric pressure sensor (Setra Systems, Inc., Boxborough, Mass.). Precipitation was recorded using a $30.5 \mathrm{~cm}$ in diameter Model 385-L Met One (Met One Instruments, Grant Pass, Ore.) AC-powered heated precipitation gauge. Wind speed and direction at $3 \mathrm{~m}$ height were monitored using a Model 034B cup anemometer (Met One Instruments, Grant Pass, Ore.) that had a wind speed range of $0-44.7 \mathrm{~m} \mathrm{~s}^{-1}$ with a starting threshold of $0.28 \mathrm{~m} \mathrm{~s}^{-1}$. All variables were sampled at $30 \mathrm{~s}$ intervals and averaged and recorded every hour for energy balance calculations using a Model CR10X datalogger and AM416 relay multiplexer (Campbell Scientific, Inc., Logan, Utah). The BREBS was closely supervised and general maintenance was provided at least once a week. Maintenance included cleaning the thermocouples and housing units (exchanger tubes), servicing radiometers by cleaning domes, checking/replacing the desiccant tubes, and making sure that the radiometers were properly leveled. The radiometer domes were replaced every 3-4 months. The BREBS data were downloaded from the datalogger every week and carefully screened (Irmak and Irmak 2008; Irmak and Mutiibwa 2008). 
Comparison of Measured Actual and Computed Reference Evapotranspiration

Reference ET using the ASCE standardized reference ET equations was calculated for the nongrowing periods using a carefully screened dataset obtained from a nearby High Plains Regional Climate Center (2007) weather station; http://www. hprcc.unl.edu. The automated weather station from which the data were obtained was located approximately $1 \mathrm{~km}$ from the study field. $\mathrm{ET}_{0}$ and $\mathrm{ET}_{r}$ were computed following the procedures given in ASCE-EWRI (2005) as detailed in Irmak et al. (2003, 2005, 2006, 2008a,c). ET ${ }_{o}$ and $\mathrm{ET}_{r}$ values were calculated on an hourly basis and summed for $24 \mathrm{~h}$ to match the hourly energy balance calculations from the BREBS. A generalized version of Spearman's rank correlation, which can detect monotonic and non- monotonic relationships (Harrell 2001), was used to evaluate the correlation between $\mathrm{ET}_{c}$ and $\mathrm{ET}_{\text {ref }}$ BREBS measured variables, and day of the nongrowing season. Linear regression was used to evaluate the strength of the linear relationship between daily $\mathrm{ET}_{\text {ref }}$ and $\mathrm{ET}_{c}$.

\section{Surface Coefficients and $K_{c} \cdot E T_{\text {ref }}$}

Surface coefficients (a more generic term used here in place of crop coefficients to include conditions where a green crop is absent) were calculated as the ratio of BREBS-measured ET to both $\mathrm{ET}_{o}$ and $\mathrm{ET}_{r}$. The distributions of these surface coefficients $\left(K_{c o}\right.$ and $\left.K_{c r}\right)$ were evaluated and average nongrowing season $K_{c}$ values were calculated. There were 40 negative $K_{c}$ values out of 594 total values that were excluded from the distribution fitting and average calculations. A generalized Spearman's rank correlation (Harrell 2001) was used to evaluate the correlation between the surface coefficients and BREBS-measured variables and day of the nongrowing season. Daily estimated $\mathrm{ET}_{c}$ values were calculated as the seasonal average $K_{c}$ multiplied by $\mathrm{ET}_{\text {ref }}$ using both $\mathrm{ET}_{o}$ and $\mathrm{ET}_{r}$. These estimated $\mathrm{ET}_{c}$ values were then compared to measured $\mathrm{ET}_{c}$. The performance of the average $K_{c} \cdot \mathrm{ET}_{\text {ref }}$ approach was evaluated using root mean square deviation (RMSD) and two measures recommended by ASCE (1993), which were the cumulative deviation $\left(D_{V}\right)$ and the Nash-Sutcliffe efficiency $\left(R_{\mathrm{NS}}^{2}\right)$.

\section{FAO-56 Dual Crop Coefficient Predicted ET}

The FAO-56 dual crop coefficient method was used to estimate $\mathrm{ET}_{c}$ using the procedures and recommendations for nongrowing periods and a surface covered with dead vegetation (Allen et al. 1998; 2005a,b). In the dual crop coefficient method, $K_{c}$ is calculated as the sum of a basal crop coefficient $\left(K_{c b}\right)$ and a soil evaporation coefficient $\left(K_{e}\right)$. Since there was no live crop, $K_{c b}$ was assumed to be 0 . The soil evaporation coefficient, $K_{e^{\prime}}$ was computed using a daily soil water balance as described in FAO-56 (Allen et al. 1998) with the following assumptions. Total evaporable water (TEW) was estimated using FAO-56 [Eq. (73)] using field capacity and permanent wilting point values for the Hastings silt loam soil at the experimental field and an assumed depth subject to drying by evaporation, $Z_{e^{\prime}}$ of $0.15 \mathrm{~m}$, which resulted in a TEW value of $40.5 \mathrm{~mm}$. This TEW value was reduced to account for residue cover using a reduction of $5 \%$ for each $10 \%$ of residue cover as suggested in FAO-56. Since residue cover was not measured during the study periods, it was estimated to be $80 \%$ based on corn yields and overwinter weathering using tabular values and the calculation method from Shelton et al. (2000), and it was assumed to be constant throughout the nongrowing season each year. Therefore, the TEW used for the water balance calculations was 24.3 $\mathrm{mm}$. The readily evaporable water (REW) was estimated as $9.5 \mathrm{~mm}$, which was the midpoint of the range of values given in FAO-56 Table 19 for silt loam soils. The fraction of the soil surface wetted $\left(f_{w}\right)$ was assumed to be 1.0. An upper limit was placed on the value of $K_{e}$ using a maximum surface coefficient $\left(K_{c \max }\right)$ of 1.20 for a completely wet surface with no live vegetation. Once a value for $K_{e}$ was determined, $\mathrm{ET}_{c}$ was calculated as $K_{c} \cdot$ ET $_{o^{\prime}}$ where $K_{c}=K_{e}$.

Regression Models for $\mathrm{ET}_{\mathrm{c}}$

A multiple linear regression approach was used to develop models relating daily $\mathrm{ET}_{c}$ to daily $\mathrm{ET}_{\text {ref }}$. Both $\mathrm{ET}_{c}$ and $\mathrm{ET}_{\text {ref }}$ were time series with strong positive serial autocorrelation (as confirmed by Durbin-Watson tests and autocorrelation plots), which violates the assumptions of linear regression. Therefore, the inclusion of lagged variables was investigated to reduce the autocorrelation. In addition, there was a general trend of greater $\mathrm{ET}_{c}$ values at the beginning and end of the nongrowing season with lesser values during the middle of the nongrowing season. Therefore, linear and quadratic terms for the day of the nongrowing season (days since October 15) were included in the model as well. The final model structure was

$$
\mathrm{ET}_{c, t}=\beta_{0}+\beta_{1} t^{2}+\beta_{2} t+\beta_{3} \mathrm{ET}_{\text {ref }, t}+\beta_{4} \mathrm{ET}_{\mathrm{ref}, t-1}+\beta_{5} \mathrm{ET}_{c, t-1}+\varepsilon
$$

where $\mathrm{ET}_{c, t}=$ actual ET at day $t ; t=$ number of days since October 15; $\mathrm{ET}_{\mathrm{ref}, \mathrm{t}}=$ reference $\mathrm{ET}$ at day $t ; \mathrm{ET}_{\text {ref,t-1 }}=$ reference $\mathrm{ET}$ at day $t-1 ; \mathrm{ET}_{c, t-1}=$ actual ET at day $t-1$, the $\beta s=$ regression parameters; and $\varepsilon=$ error term, which was assumed to be distributed normally with mean zero and variance $\sigma^{2}$. Two separate models were fit to the data, one for $\mathrm{ET}_{o}$ and one for $\mathrm{ET}_{r^{\prime}}$ using data pooled from all three seasons. Akaike's information criteria (AIC) was used to determine whether simpler models and a more complex mixed effects model would perform as well or better than the chosen models, but the chosen models performed the best as measured by AIC. Although the autocorrelation was greatly reduced, the chosen models still had some minor autocorrelation (Durbin-Watson statistics $\approx 1.8$ for some lags between 2 and 7 ). However, in the interest of simpler models and since prediction was the goal instead of effect determination, additional lags or autoregressive models were not investigated. The performance of the models for predicting $\mathrm{ET}_{c}$ was evaluated using RMSD, cumulative deviation $\left(D_{V}\right)$, and Nash-Sutcliffe efficiency $\left(R_{\mathrm{NS}}^{2}\right)$. As a type of validation, the models were tested by using an initial estimate of average $K_{c} \cdot \mathrm{ET}_{\text {ref }}$ for $\mathrm{ET}_{c^{\prime} t-1}$ corresponding to October 15 of each season. The regression models developed were then used to estimate $\mathrm{ET}_{c^{\prime} t}$ for each subsequent day using the previous day's estimate for $\mathrm{ET}_{c^{\prime} t-1}$. The validation was evaluated in comparison to the measured $\mathrm{ET}_{c}$ values using the same performance measures (RMSD, $D_{V}$, and $R_{\mathrm{NS}}^{2}$ ).

\section{Results and Discussion}

\section{Surface Energy Fluxes and Precipitation}

Long-term average precipitation at the Clay Center, Nebraska, station for the defined nongrowing period (October 15April 30) is $220 \mathrm{~mm}$. Based on the long-term average, Season I 


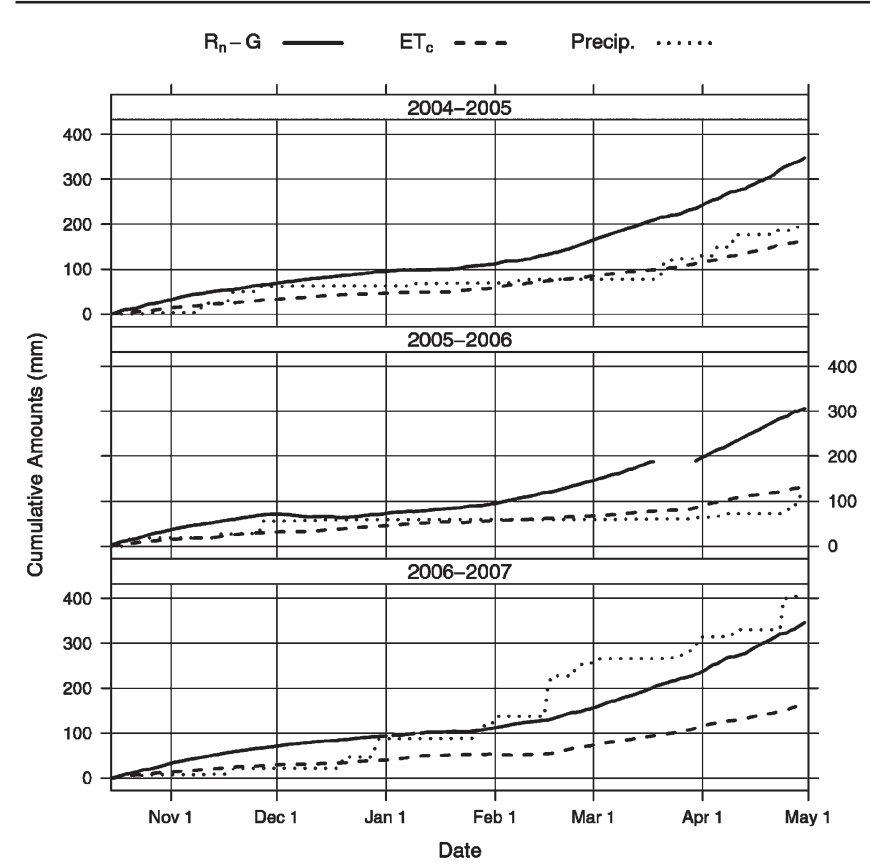

Figure 1. Cumulative available energy $\left(R_{n}-G\right)$, precipitation, and measured $\mathrm{ET}_{c}$ expressed as mm of water by season.

precipitation was $88 \%$ of normal, Season II precipitation was $50 \%$ of normal, and Season III precipitation was $184 \%$ of normal. Net radiation $\left(R_{n}\right)$ and soil heat flux $(G)$ were very similar in Seasons I and III, whereas magnitudes of the fluxes were different and considerably less in Season II (Table 1). Trends in the available energy $\left(R_{n}-G\right)$ in Seasons I and III were also very similar (Figure 1). In Seasons I and II, ET and precipitation followed the same trend and magnitude with both of them being very similar until April. Starting from April, precipitation was above $\mathrm{ET}_{c}$ in Season I, whereas it was less than precipitation in Season II. Different trends were observed in Season III where precipitation was above measured $\mathrm{ET}_{c}$ from January until May. Measured ET from the BREBS was equal between Seasons I (166 mm) and III $(167 \mathrm{~mm})$ but less in Season II (133 mm). Using the evaporative fraction concept of Nichols and Cuenca (1993), 47, 41, and 48\% of the available energy was used for $\mathrm{ET}_{c}$ in Seasons I, II, and III, respectively. Precipitation varied greatly between the three seasons. Cumulative precipitation was 194, 110, and $404 \mathrm{~mm}$ for Seasons I, II, and III, respectively, and the ratio of ET to precipitation was $0.85,1.21$, and 0.41 in the first, second, and third seasons, respectively. Since precipitation was much greater in Season III than in Season I, whereas $\mathrm{ET}_{c}$ was nearly equal, this indicates that there was more effective precipitation available to recharge the soil profile during Season III.

\section{Measured $E T_{c}$ in Relation to Reference ET and Other Variables}

Reference ET (both $\mathrm{ET}_{o}$ and $\mathrm{ET}_{r}$ ) outpaced measured $\mathrm{ET}_{c}$ in all three seasons (Figure 2). Cumulative $\mathrm{ET}_{o}$ and was 340, 420 , and $335 \mathrm{~mm}$ for Seasons I, II, and III, respectively, whereas cumulative $\mathrm{ET}_{r}$ was 460, 590, and $460 \mathrm{~mm}$, for the same seasons, respectively. As with the measured $\mathrm{ET}_{c^{\prime}} \mathrm{ET}_{o}$ and $\mathrm{ET}_{r}$ were very similar between Seasons I and III. However, ref-

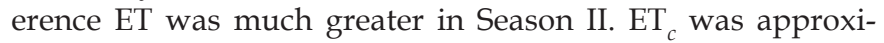
mately $50 \%$ of $\mathrm{ET}_{o}$ and $36 \%$ of $\mathrm{ET}_{r}$ in both Seasons I and III, whereas in Season II, $\mathrm{ET}_{c}$ was $32 \%$ of $\mathrm{ET}_{o}$ and $23 \%$ of $\mathrm{ET}_{r}$.

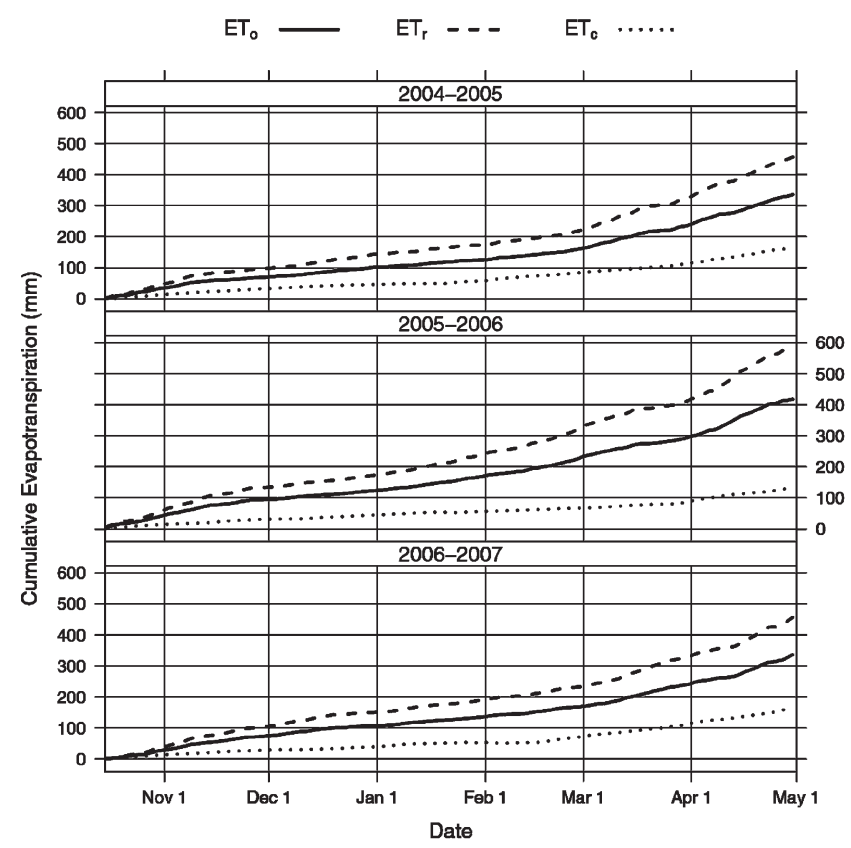

Figure 2. Cumulative measured $\mathrm{ET}_{c^{\prime}}$ grass reference ET $\left(\mathrm{ET}_{0}\right)$, and alfalfa reference ET $\left(\mathrm{ET}_{r}\right)$ by season.

Because Season II was much drier, availability of soil moisture at the surface likely limited the magnitude of $\mathrm{ET}_{c}$ during that season and would, in part, explain the much lower ratio of $\mathrm{ET}_{c}$ to the reference ET values. The linear relationship between daily $\mathrm{ET}_{c}$ and $\mathrm{ET}_{\text {ref }}$ was stronger for $\mathrm{ET}_{o}$ than $\mathrm{ET}_{r}$ as measured by the regression $R^{2}$ and root mean square deviation (Figure 3). Slopes were fairly consistent for both $\mathrm{ET}_{0}$ and $\mathrm{ET}_{r}$, but the intercepts varied by season. The weakest relationships were in Season II, which was the drier season. The average slope of the pooled data for all seasons was 1.06 for $\mathrm{ET}_{0}$

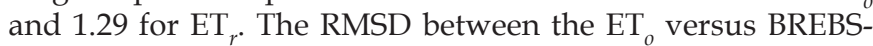
measured $\mathrm{ET}_{c}$ was $1.57 \mathrm{~m} \mathrm{day}^{-1}$, whereas it was higher $(2.42$ $\mathrm{mm} \mathrm{day}^{-1}$ ) for $\mathrm{ET}_{r}$ versus $\mathrm{ET}_{c}$.

Overall, measured $\mathrm{ET}_{c}$ was generally most strongly correlated with radiation terms, particularly $R_{n^{\prime}}$ albedo, incoming shortwave radiation, and outgoing longwave radiation (Figure 4). The correlation with albedo was a negative one, as ET was less during periods of snow cover and high albedo. Other variables for which measured $\mathrm{ET}_{c}$ had a moderately strong correlation were days since October 15, soil temperature, and air temperature. Precipitation, atmospheric pressure, outgoing shortwave radiation, wind speed, soil heat flux density, and

Table 1. Summary of Surface Energy Fluxes and Precipitation by Season

\begin{tabular}{lrrrr}
\hline Season & $\begin{array}{r}{\text { Mean } R_{n}}^{-2} \\
\left(\mathrm{MJ} \mathrm{m}^{-2} \text { day }^{-1}\right)\end{array}$ & $\begin{array}{r}\text { Mean G } \\
\left(\mathrm{MJ} \mathrm{m}^{-2} \text { day }^{-1}\right)\end{array}$ & $\begin{array}{r}\text { Cum. } \\
\text { measured } \\
\begin{array}{c}\mathrm{ET}_{c} \\
(\mathrm{~mm})\end{array}\end{array}$ & $\begin{array}{r}\text { Cum. } \\
\text { precip. } \\
(\mathrm{mm})\end{array}$ \\
\hline $2004-2005$ & 4.13 & -0.17 & 166 & 194 \\
$2005-2006$ & 3.98 & -0.03 & 133 & 110 \\
$2006-2007$ & 4.12 & -0.19 & 167 & 404 \\
\hline
\end{tabular}

Net radiation $\left(R_{n}\right)$ and soil heat flux $(G)$ are shown as daily means for comparison, because there were several days of missing data in Seasons II and III. Evapotranspiration (ET) and precipitation are shown as cumulative values for the season. 


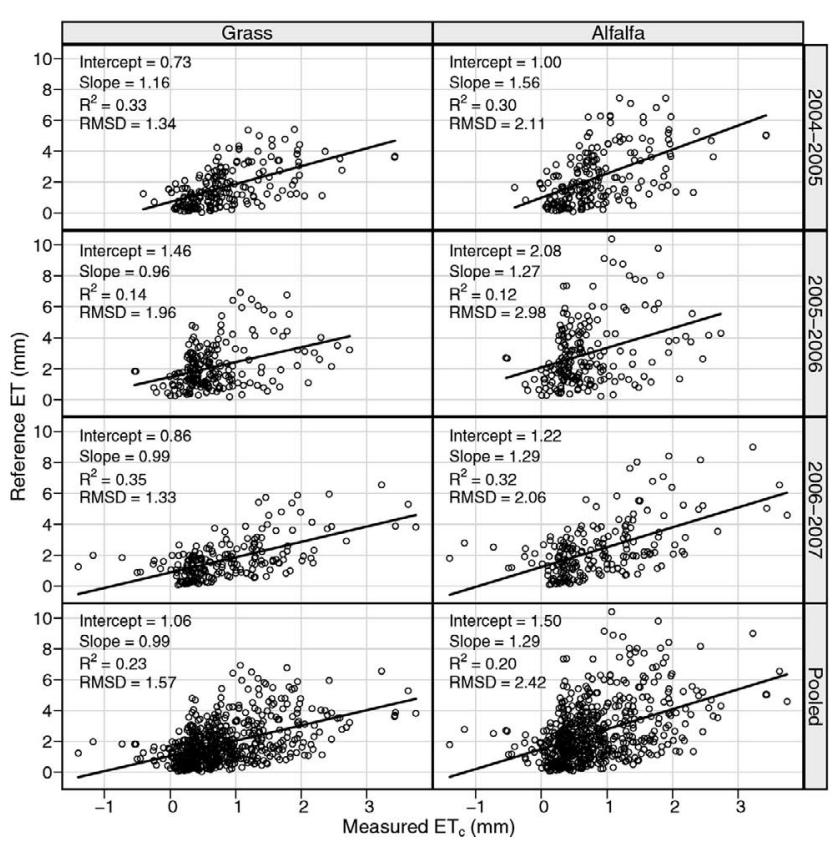

Figure 3. ASCE standardized grass and alfalfa-reference ET versus measured $\mathrm{ET}_{c}$ by season and for all seasons combined.

relative humidity were the least correlated variables with the measured $\mathrm{ET}_{c}$. Wind direction did not have any impact on the $\mathrm{ET}_{c}$ and had a $\rho^{2}$ coefficient of 0.0 . The Spearman's $\rho^{2}$ coefficient was near 0.5 for $R_{n}$, whereas it was between 0 and 0.1 for the aforementioned variables. Thus, the energy term $\left(R_{n}\right)$ and albedo (which is a function of surface characteristics) rather than the aerodynamic term had more impact on the measured $\mathrm{ET}_{c}$ during the dormant periods.

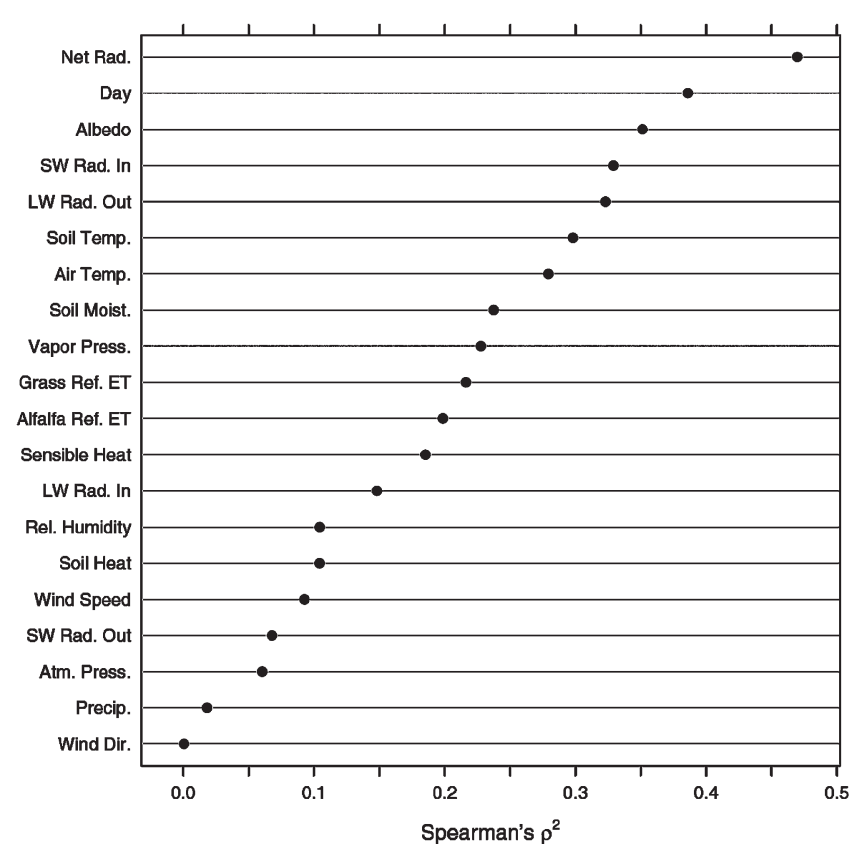

Figure 4. Correlation of measured $\mathrm{ET}_{c}$ to listed variables using generalized Spearman's $\rho^{2}$ to detect nonmonotonic as well as monotonic relationships.

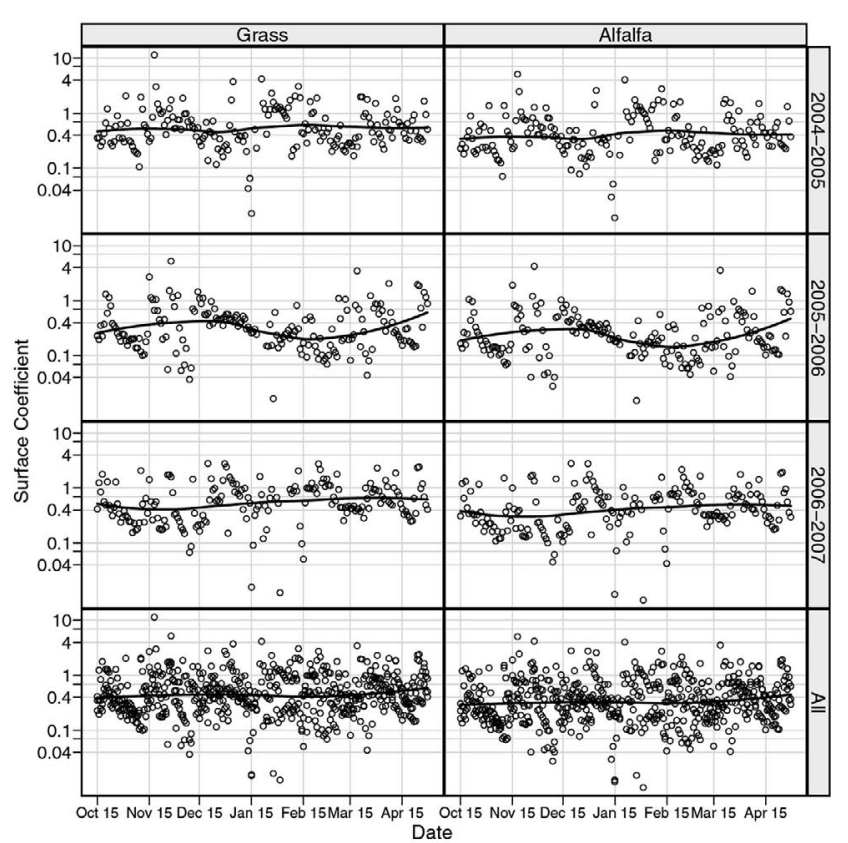

Figure 5. Surface coefficients $\left(\mathrm{ET}_{c} / \mathrm{ET}_{\mathrm{ref}}\right)$ and locally estimated regression (LOESS) smoothed lines for grass $\left(K_{c o}\right)$ and alfalfa $\left(K_{c r}\right)$ reference ET by season and for all season combined.

\section{Surface Coefficients}

There was considerable variation in the daily surface coefficients, $K_{c}$ (Figure 5). Locally estimated regression (LOESS) smoothed lines showed some trends but, with the exception of Season II, did not vary greatly from the mean. In Season II, the surface coefficients increased from October until mid-December when the surface was free of snow cover. From December until early March the coefficients decreased gradually as

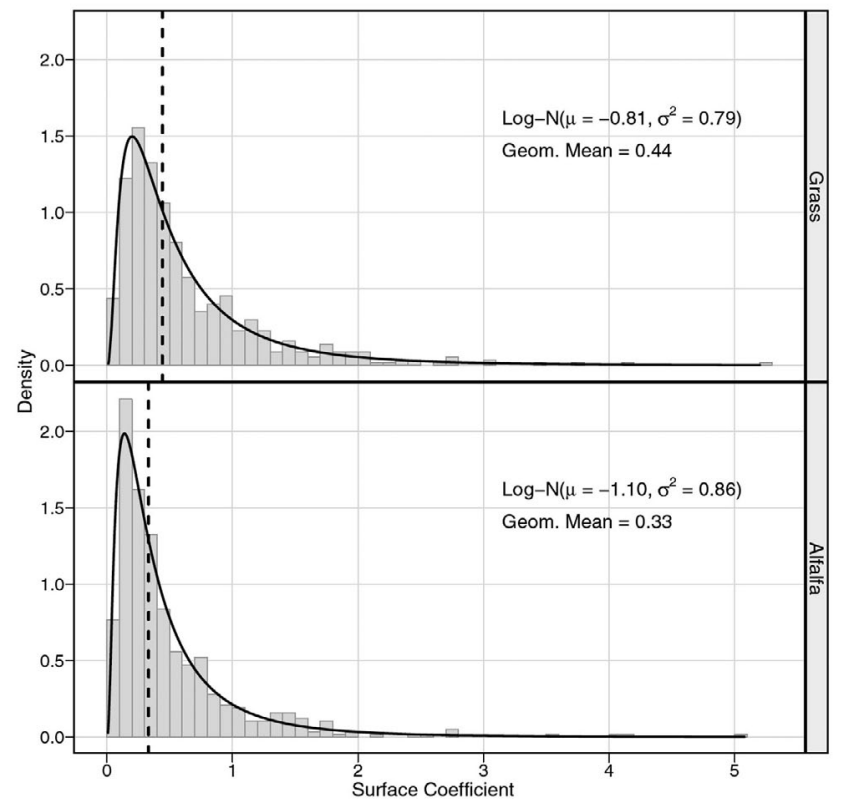

Figure 6. Histograms of surface coefficients $\left(\mathrm{ET}_{c} / \mathrm{ET}_{\mathrm{ref}}\right)$ for grass $\left(K_{c o}\right)$ and alfalfa $\left(K_{c r}\right)$ reference ET with fitted log-normal distribution densities superimposed (solid lines) and geometric means indicated (dashed vertical lines). 


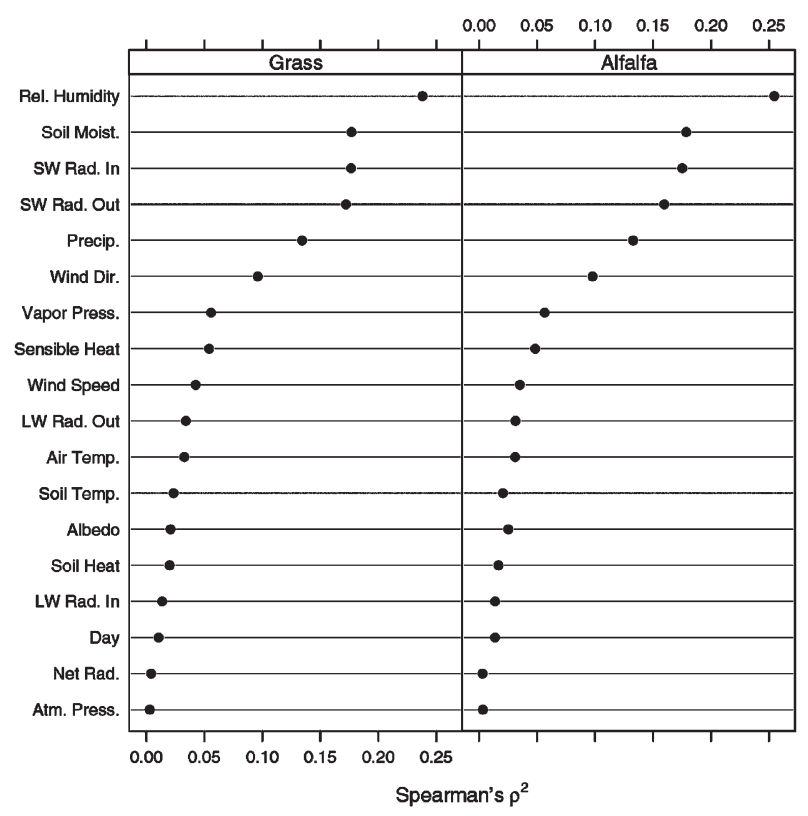

Figure 7. Correlation of surface coefficients $\left(\mathrm{ET}_{c} / \mathrm{ET}_{\mathrm{ref}}\right)$ for grass and alfalfa reference ET to listed variables using generalized Spearman's $\rho^{2}$ to detect nonmonotonic as well as monotonic relationships.

the ratio of $\mathrm{ET}_{c}$ to $\mathrm{ET}_{\text {ref }}$ decreased due to snow cover and frozen surface conditions and gradually increased until the end of April. The $K_{c}$ values generally followed a log-normal distribution (Figure 6). This was confirmed by the results of Kolmogorov-Smirnov goodness-of-fit tests, which failed to reject the null hypothesis that the $K_{c}$ values were from the same lognormal distributions indicated in Figure 6 for both grass $(D$ $=0.03, p=0.68)$ and alfalfa $(D=0.03, p=0.68)$ reference. Because the $K_{c}$ values were log-normally distributed, geometric means were used to represent the average $K_{c}$ values. The geometric mean $K_{c}$ values for the three seasons combined were 0.44 and 0.33 for $\mathrm{ET}_{o}$ and $\mathrm{ET}_{r}$, respectively. These values are comparable to values reported in Allen et al. (1998) for nongrowing periods, and slightly less than the average value of 0.50 used for ET by Allen (1996). Values in our study include periods of snow cover, whereas the 0.50 used by Allen (1996) was only for periods without snow cover. If measurements are not available, it is difficult to identify whether or not the surface is covered with snow on any given day. The surface coefficients were most strongly correlated with relative humidity (Figure 7). There was some correlation with soil moisture, shortwave radiation, and precipitation, but correlations with the other variables were generally weak. Closer inspection of the relationship between the surface coefficients and the most strongly correlated variables indicates that while large surface coefficient values generally occurred during conditions of high humidity and soil moisture and low shortwave radiation, there were also large numbers of small surface coefficient values during these conditions (Figure 8). So, these conditions do not necessarily lead to large surface coefficients.

Using the geometric mean $K_{c}$ values to calculate $\mathrm{ET}_{c}$ as $K_{c}$. $\mathrm{ET}_{\text {ref }}$ over the entire nongrowing season yielded adequate predictions (Figure 9) with overall root mean square deviations of 0.64 and $0.67 \mathrm{~mm} \mathrm{day}^{-1}$ for $\mathrm{ET}_{o}$ and $\mathrm{ET}_{r}$, respectively. These error estimates are similar and slightly better than those of Allen (1996) using a similar approach. Predictions were better in
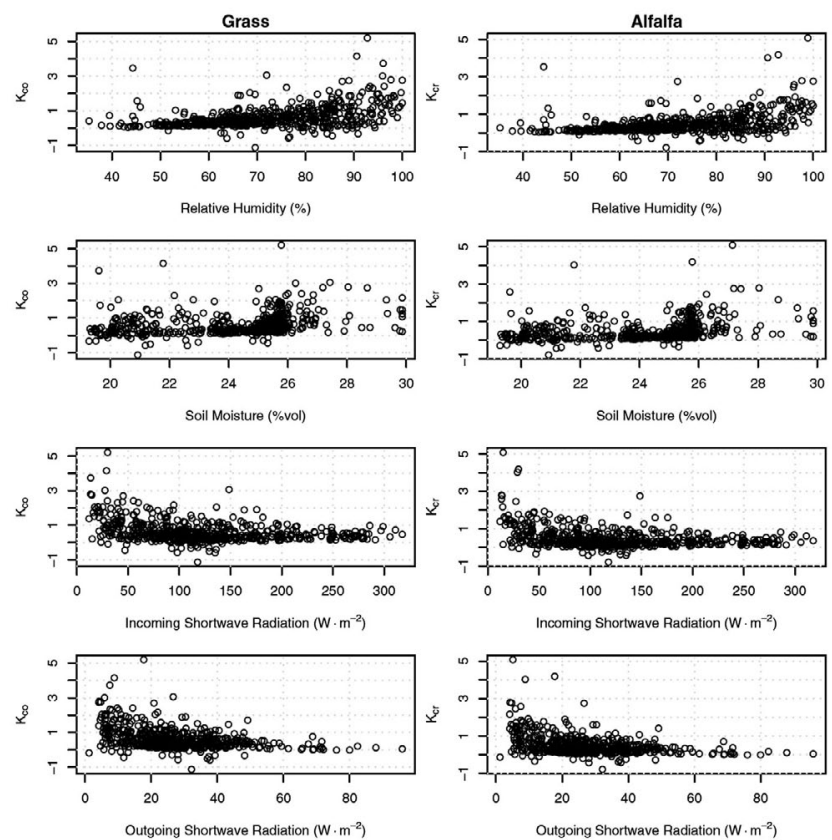

Figure 8. Grass and alfalfa-reference average surface coefficient values [average of 2004-2005 (Season I), 2005-2006 (Season II), and 2006-2007 (Season III)] as function of relative humidity, soil moisture, incoming shortwave radiation, and outgoing shortwave radiation.

the average and wet seasons (Seasons I and III) and worse in

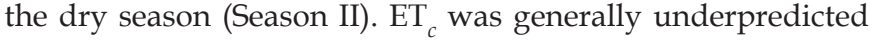
in the average and wet season and overpredicted in the dry season. Cumulative predicted $\mathrm{ET}_{c}$ was within about $10 \%$ of measured ET in Seasons I and III but was overpredicted by about $40 \%$ in Season II.

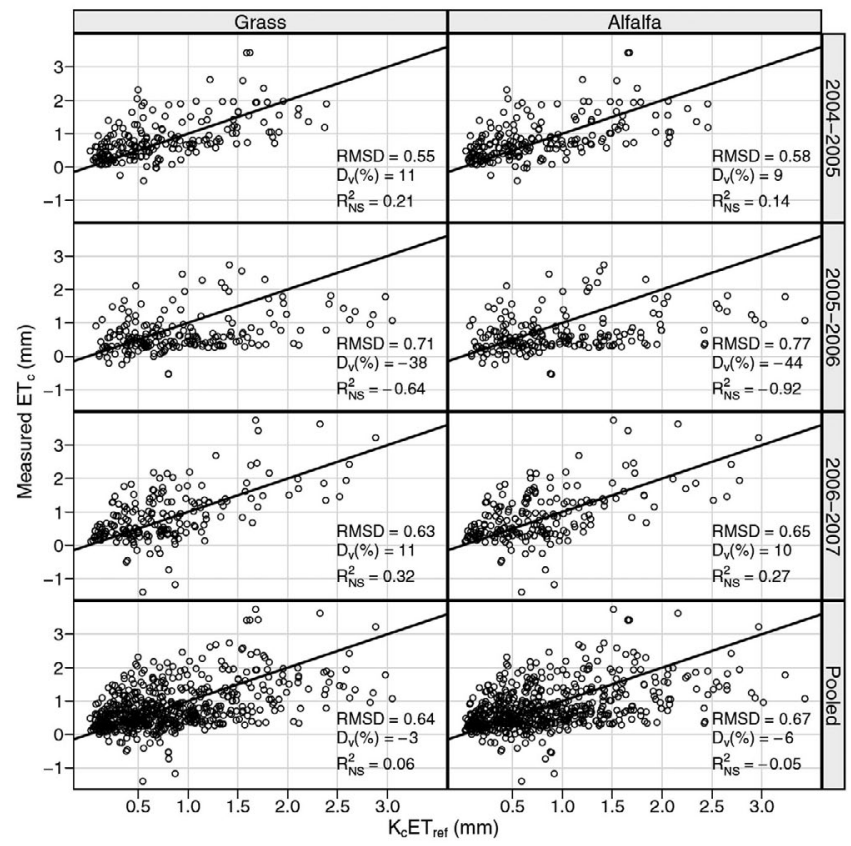

Figure 9. Relationship between measured $\mathrm{ET}_{c}$ and $\mathrm{ET}_{c}$ estimated as $K_{c} E_{\text {ref }}$ for grass and alfalfa-reference ET by season and for all seasons combined (pooled data). Solid lines are 1:1 lines. 
Table 2. Summary Statistics of Surface Coefficients from Measured ET ${ }_{c}$ and FAO-56 Calculated Surface Coefficients for Use with ET ${ }_{o}$

\begin{tabular}{|c|c|c|c|c|c|c|}
\hline Season & Min. & $\begin{array}{l}\text { First } \\
\text { quarter }\end{array}$ & Median & Mean & $\begin{array}{l}\text { Third } \\
\text { quarter }\end{array}$ & Max. \\
\hline \multicolumn{7}{|c|}{ (a) Measured $K_{c o}$} \\
\hline 2005-2006 & -0.45 & 0.18 & 0.27 & 0.46 & 0.49 & 5.20 \\
\hline 2006-2007 & 0.09 & 0.34 & 0.56 & 0.77 & 1.01 & 2.79 \\
\hline Pooled & -0.45 & 0.25 & 0.45 & 0.68 & 0.86 & 11.42 \\
\hline $2004-2005$ & 0.00 & 0.17 & 0.34 & 0.53 & 1.08 & 1.20 \\
\hline 2005-2006 & 0.00 & 0.01 & 0.07 & 0.32 & 0.55 & 1.20 \\
\hline 2006-2007 & 0.03 & 0.23 & 0.77 & 0.72 & 1.20 & 1.20 \\
\hline Pooled & 0.00 & 0.08 & 0.37 & 0.52 & 1.08 & 1.20 \\
\hline
\end{tabular}

\section{FAO-56 Dual Crop Coefficient Predicted ET}

Surface coefficients calculated using the FAO-56 dual crop coefficient method ranged from near 0 to the imposed limit of 1.2 (Table 2, Figure 10). Mean and median $K_{c}$ values from the FAO-56 dual crop coefficient method were generally less than the measured $K_{c o}$ values; however, the third quartile values were greater (Table 2). The FAO-56 calculated values were limited to a maximum of 1.2 , but there were a number of days where the measured $K_{c o}$ values exceeded this value. Whereas, the measured $K_{c}$ values showed considerable day-to-day fluctuations (Figure 5), the FAO-56 calculated surface coefficients followed recognizable trends based on the estimated soil water status. On a cumulative basis, the FAO-56 dual crop coefficient method generally predicted $\mathrm{ET}_{c}$ better than the average $K_{c} \cdot \mathrm{ET}_{\text {ref }}$ method with an overall $D_{v}$ of $0 \%$. The exception was for the wet season (Season III). However, the average $K_{c} \cdot \mathrm{ET}_{\text {ref }}$ method generally performed better on a daily basis. Using the FAO-56 dual crop coefficient method, $\mathrm{ET}_{c^{\prime}}$, was generally underpredicted in the dry season and overpredicted during the wet

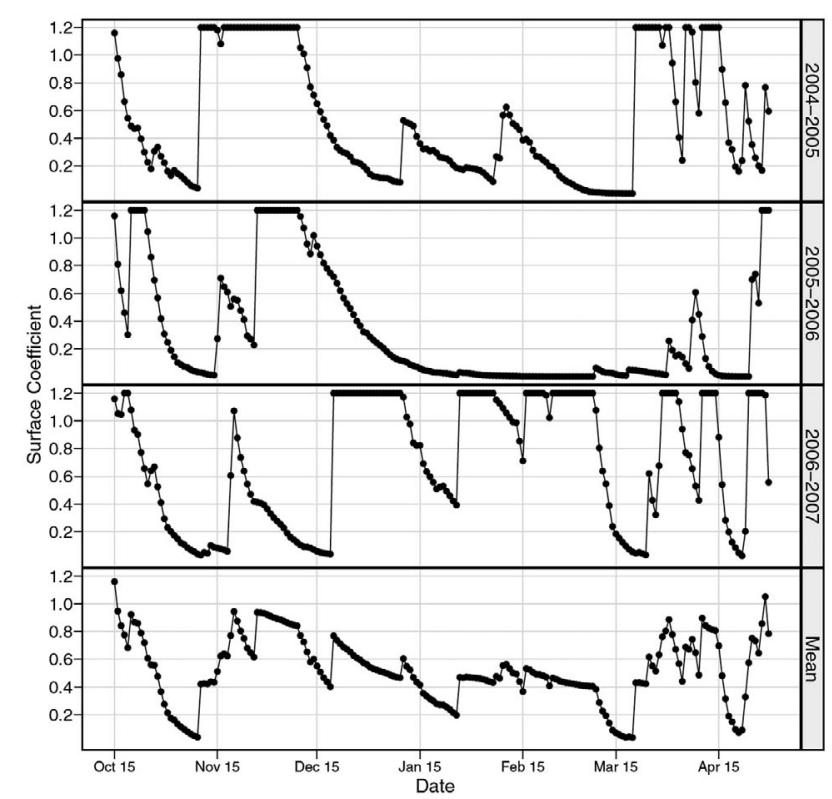

Figure 10. Surface coefficients $\left(\mathrm{ET}_{c} / \mathrm{ET}_{0}\right)$ as calculated using FAO-56 dual crop coefficient method by season and the mean for all seasons combined. season, whereas the opposite was true for the average $K_{c} \cdot \mathrm{ET}_{\text {ref }}$ method. The $R_{\mathrm{NS}}^{2}$ values for the FAO-56 dual crop coefficient method were all less than zero, which indicates that the observed mean was a better predictor. The FAO-56 dual crop coefficient method calculations, while relatively simple to apply, require a number of parameters. Field measurements may not exist for many of these parameters, so values must be estimated based on soil type or assumed. Seasonal differences in the results suggest that same of these values may vary seasonally.

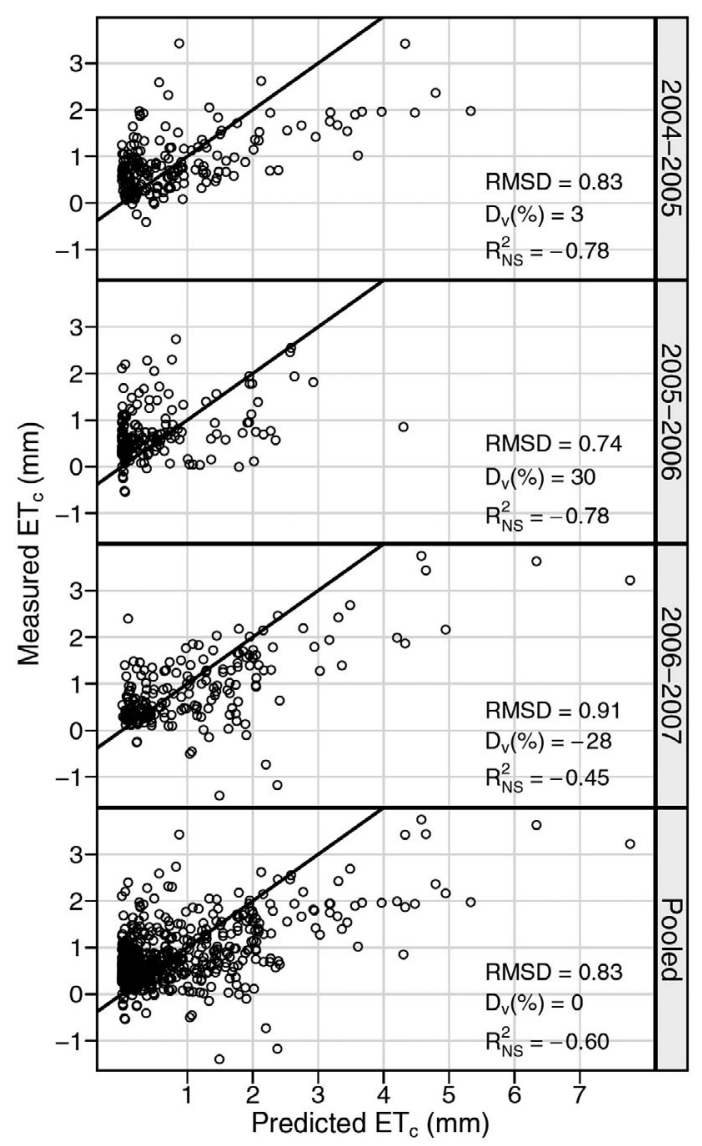

Figure 11. Relationship between measured $\mathrm{ET}_{c}$ and $\mathrm{ET}_{c}$ predicted using FAO-56 dual crop coefficient method by season and for all seasons combined (pooled data). Solid lines are 1:1 lines. 
Table 3. Summary of Multiple Linear Regression Models for Predicting $\mathrm{ET}_{c}$ Based on $\mathrm{ET}_{\text {ref }}$ and Day of Nongrowing Season, Where $\mathrm{ET}_{c, t}=$ Crop ET at Day $t ; t=$ Number of Days since October 15, $\mathrm{ET}_{o, t}=$ Grass Reference ET at Day $t ; \mathrm{ET}_{r, t}=$ Alfalfa Reference ET at Day $t ; \mathrm{ET}_{0, t-1}=$ Grass Reference ET at Day $t-1$, $\mathrm{ET}_{r, t-1}=$ Alfalfa Reference ET at Day $t-1$; and $\mathrm{ET}_{c, t-1}=$ Crop ET at Day $t-1$

\begin{tabular}{lccrc}
\hline Coefficient & Estimate & Std. error & $t$ value & $\operatorname{Pr}(>|t|)$ \\
\hline \multicolumn{4}{c}{ (a) Grass reference ET } \\
\hline Intercept & 0.62 & 0.07 & 8.53 & $<0.001$ \\
$t^{2}$ & $-9.9 \times 10^{-3}$ & $1.4 \times 10^{-3}$ & -6.97 & $<0.001$ \\
$t$ & $6.7 \times 10^{-5}$ & $7.7 \times 10^{-6}$ & 8.69 & $<0.001$ \\
ET $_{o, t}$ & 0.13 & 0.02 & 7.09 & $<0.001$ \\
$\mathrm{ET}_{o, t-1}$ & -0.18 & 0.02 & -9.77 & $<0.001$ \\
$\mathrm{ET}_{c, t-1}$ & 0.47 & 0.03 & 13.53 & $<0.001$
\end{tabular}

Adjusted $R^{2}: 0.61$

$F$ statistic: 184.1 on 5 and $585 \mathrm{DF}, p$ value: $<0.001$

\begin{tabular}{lccrl}
\hline \multicolumn{5}{c}{ (b) Alfalfa reference ET } \\
\hline Intercept & 0.62 & 0.07 & 8.66 & $<0.001$ \\
$t^{2}$ & $-9.9 \times 10^{-3}$ & $1.4 \times 10^{-3}$ & -7.02 & $<0.001$ \\
$t$ & $6.7 \times 10-5$ & $7.6 \times 10-6$ & 8.80 & $<0.001$ \\
$\mathrm{ET}_{r, t}$ & 0.08 & 0.01 & 6.72 & $<0.001$ \\
$\mathrm{ET}_{r^{\prime} t-1}$ & -0.12 & 0.01 & -9.54 & $<0.001$ \\
$\mathrm{ET}_{c^{\prime} t-1}$ & 0.46 & 0.03 & 13.38 & $<0.001$
\end{tabular}

$F$ statistic: 181.3 on 5 and $585 \mathrm{DF}, p$ value: $<0.001$

While the FAO-56 dual crop coefficient method requires more information, it allows for a more detailed analysis of the water balance over the nongrowing period (see Figure 11).

\section{Daily ET $T_{c}$ Regression Models}

The daily $\mathrm{ET}_{c}$ regression models developed using $\mathrm{ET}_{\text {ref }}$, information from the previous day, and day of the nongrowing season improved predictions of $\mathrm{ET}_{c}$ considerably over the average surface coefficient method and the FAO-56 dual crop coefficient method (Table 3, Figure 12). Root mean square deviations were approximately $0.40 \mathrm{~mm}$ day $^{-1}$ for the developed models. Predicted cumulative $\mathrm{ET}_{c}$ was within $3 \%$ of measured cumulative $\mathrm{ET}_{c}$ in the average and wet seasons (Seasons I and III) and within $7 \%$ in the dry season (Season II). Applying the developed regression equations as they might be used in practice to validate the models resulted in only a moderate decrease in performance (Figure 13). Root mean square deviations using the validation data were approximately $0.40-0.50$ $\mathrm{mm}$ day $^{-1}$. Predicted cumulative ET remained within $5 \%$ of measured $\mathrm{ET}_{c}$ for the validation data during Seasons I and III but the overprediction in Season II increased to approximately 13\%. Overall Nash-Sutcliffe model efficiencies were 0.61 for the regression models as developed and 0.49 for the validation. The regression models developed are specific to the conditions of this study, and further testing would be required to evaluate their application to other conditions.

\section{Cumulative $E T_{c}$}

Cumulative daily $\mathrm{ET}_{c}$ values from BREBS measurements, the average $K_{c o} \cdot \mathrm{ET}_{o}$ approach, FAO-56 dual $K_{c}$ approach, and the regression equation developed using $\mathrm{ET}_{0}$ are presented in Figure 14 for the three seasons. In Season I (average season), all methods provided very good $\mathrm{ET}_{c}$ estimates and were very close to the BREBS-measured $\mathrm{ET}_{c}$. The cumulative $\mathrm{ET}_{c}$ val-

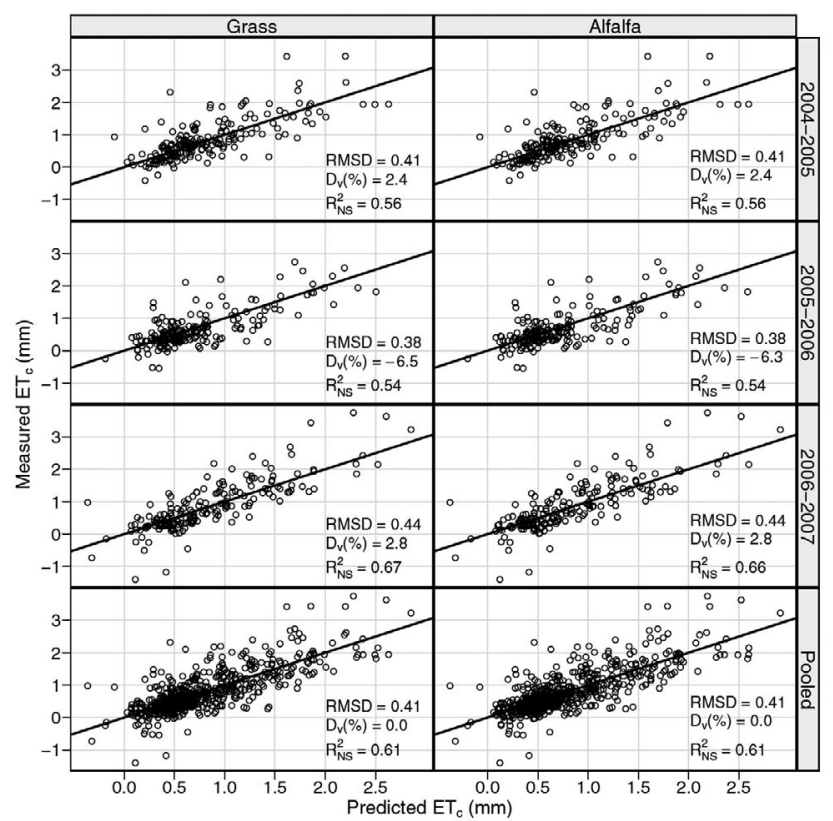

Figure 12. Relationship between measured $\mathrm{ET}_{c}$ and $\mathrm{ET}_{c}$ predicted using developed multiple linear regression equations for grass and alfalfa reference ET by season and for all seasons combined (pooled data). Solid lines are 1:1 lines.

ues for the aforementioned methods, respectively, were 166, 148,160 , and $158 \mathrm{~mm}$. The FAO-56 method provided the closest $\mathrm{ET}_{c}$ estimates to the measured values. The average $K_{c o} \cdot \mathrm{ET}_{o}$ approach was underestimated by $18 \mathrm{~mm}$. In Season II (dry

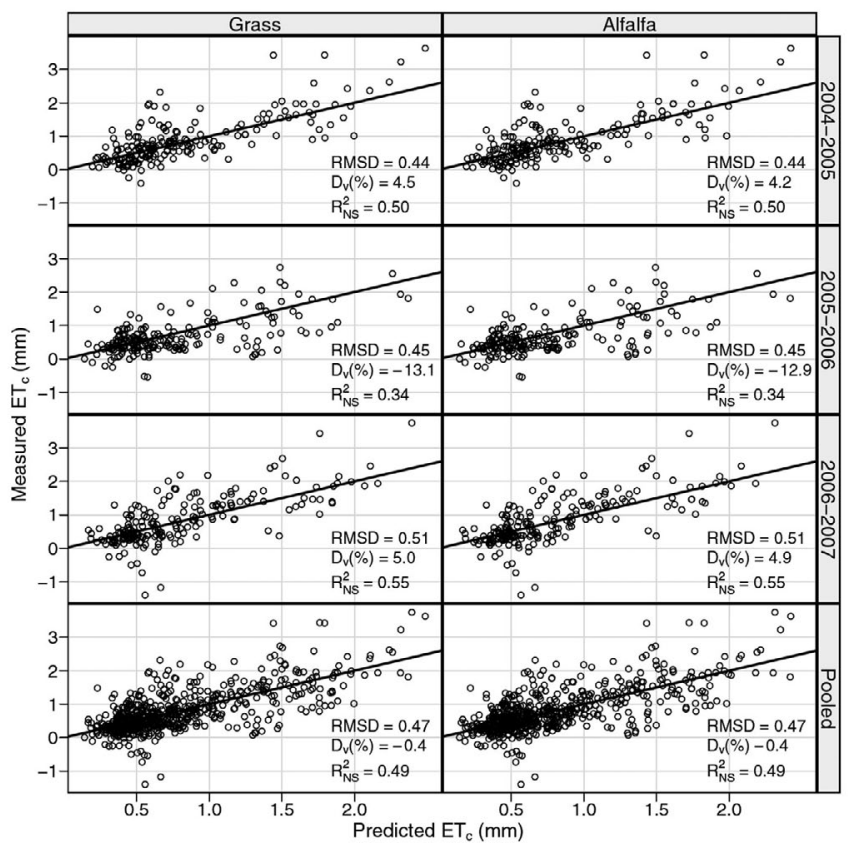

Figure 13. Relationship between measured $\mathrm{ET}_{c}$ and $\mathrm{ET}_{c}$ predicted using developed multiple linear regression equations validated using initial $\mathrm{ET}_{c}$ estimate for first prediction and predicted $\mathrm{ET}_{c}$ values for subsequent predictions for grass and alfalfa reference ET by season and for all seasons combined (pooled data). Solid lines are 1:1 lines. 


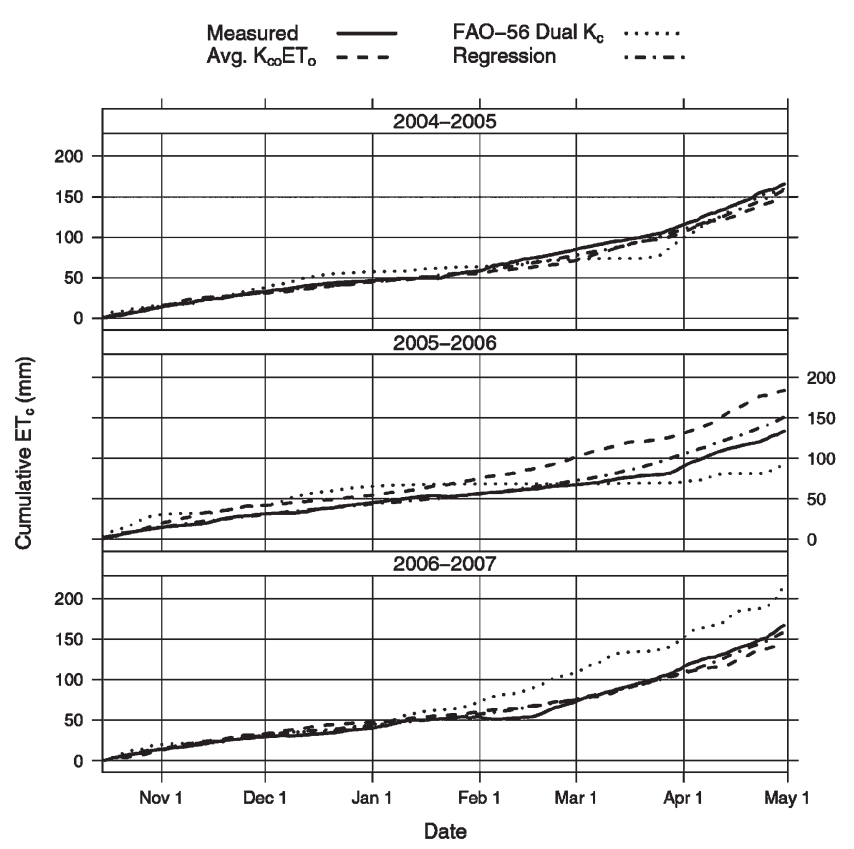

Figure 14. Cumulative measured $\mathrm{ET}_{c^{\prime}}$ and $\mathrm{ET}_{c}$ estimated from average $K_{c o} \cdot \mathrm{ET}_{o}$ method, FAO-56 dual $K_{c}$ method, and the regression equation developed using $\mathrm{ET}_{0}$ by season.

season), the estimates of the regression approach were closest to the measured values (151 versus $134 \mathrm{~mm}$ ). The average $K_{c o} \cdot \mathrm{ET}_{o}$ approach was overestimated by $50 \mathrm{~mm}$, whereas the FAO-56 dual $K_{c}$ approach was underestimated by $40 \mathrm{~mm}$. In Season III (wet season), the average regression method, again, provided the closest estimates to the measured $\mathrm{ET}_{c}$ values. The estimate of the regression approach $(159 \mathrm{~mm})$ was only $8 \mathrm{~mm}$ lower than the measured cumulative $\mathrm{ET}_{c}(167 \mathrm{~mm})$. Unlike the performance in Season II, the FAO-56 dual $K_{c}$ approach overestimated BREBS-measured $\mathrm{ET}_{c}$ by $46 \mathrm{~mm}$. The average $K_{c o}$. $\mathrm{ET}_{o}$ approach estimates were within $11 \%$ of the measured $\mathrm{ET}_{c}$.

While the estimates of the average $K_{c o} \cdot \mathrm{ET}_{o}$ and regression approach provided close estimates to the measured $\mathrm{ET}_{c}$, their estimates might be somewhat influenced from the fact that the $K_{c}$ values used in these approaches were calculated using the measured $\mathrm{ET}_{c}$ values (i.e., $K_{c}=\mathrm{ET}_{c} / \mathrm{ET}_{0}$ ). Although, the $\mathrm{ET}_{c}$ values estimated using the FAO-56 dual $K_{c}$ approach were deviated from the measured $\mathrm{ET}_{c}$ values more than the other two approaches in wet and dry years, their estimates can be considered as a more independent measure of the $\mathrm{ET}_{c}$ because it uses independent $K_{c}$ values. The over- and underestimation of the FAO-56 dual $K_{c}$ approach might be due to the impact of assuming a constant residue cover percentage (80\%) of the maize field throughout the study period in all seasons. When calculating the dual $K_{c}$ values with the FAO-56 approach, we set the basal $K_{c}$ to zero for bare soil because the approach does not account for the residue cover impact on basal $K_{c}$. Accounting for the impact of the residue decay rate on the REW and TEW by a variable residue decay function may improve the $\mathrm{ET}_{c}$ estimates of the FAO-56 dual $K_{c}$ approach in the dry and wet seasons.

\section{Conclusions}

Available energy and evapotranspiration and the relationship between measured $\mathrm{ET}_{c}$ and $\mathrm{ET}_{\text {ref }}$ of a maize residue-cov- ered field were evaluated for three consecutive nongrowing periods. $\mathrm{ET}_{c}$ was approximately $50 \%$ of both available energy and $\mathrm{ET}_{\text {ref }}$ during the normal and above normal precipitation seasons. During the season with below normal precipitation, $\mathrm{ET}_{c}$ was a smaller percentage of available energy and $\mathrm{ET}_{\text {ref }}$. The availability of soil moisture at the surface likely limited the ET during the drier season. Geometric mean surface coefficients for the three seasons combined were 0.44 and 0.33 for $\mathrm{ET}_{o}$ and $\mathrm{ET}_{r^{\prime}}$ respectively. Using average $K_{c}$ multiplied by $\mathrm{ET}_{\text {ref }}$ to predict $\mathrm{ET}_{c}$ resulted in adequate predictions during average and wet nongrowing seasons with somewhat worse predictions and cumulative overpredictions during a dry season. The average $K_{c}$ method provides an easy method for estimating nongrowing season ET and may be sufficient particularly during years of normal and above-normal precipitation. The FAO-56 dual crop coefficient method requires measurements or estimates for a number of parameters and more detailed calculations, but provides more information on the soil water balance. The FAO-56 dual crop coefficient method gave good estimates of $\mathrm{ET}_{c}$ on a cumulative basis, but performed less well on a daily basis. Multiple linear regression models were developed using $\mathrm{ET}_{\text {ref }}$ information from the previous day, and day of the nongrowing season, which gave considerably improved prediction. The regression models require only minimal information but provide more accurate estimates and are less impacted by below normal precipitation seasons. The regression approach used here could be applied to other surfaces and other locations to estimate evaporative losses during nongrowing periods. Considering evaporative losses that occur in the nongrowing periods in water budget calculations would enable water regulatory agencies to better assess water resources management dynamics over the entire year rather than only for the growing season.

\section{Acknowledgments}

This paper is a contribution of the University of NebraskaLincoln, Agricultural Research Division, Lincoln, Nebraska. The mention of trade names or commercial products is solely for the information of the reader and does not constitute an endorsement or recommendation for use by the writers or the University of Nebraska-Lincoln.

\section{Notation}

The following symbols are used in this paper:

$D=$ Kolmogorov-Smirnov test statistic

$D_{V} \quad=$ cumulative deviation

ET = evapotranspiration

$\mathrm{ET}_{c}=$ actual (crop) evapotranspiration

$\mathrm{ET}_{o} \quad$ grass-reference evapotranspiration

$\mathrm{ET}_{r} \quad=$ alfalfa-reference evapotranspiration

$\mathrm{ET}_{\text {ref }}=$ reference evapotranspiration

$f_{w} \quad=$ fraction of surface wetted

$G \quad=$ soil heat flux

$K_{c} \quad=$ surface crop. coefficient

$K_{c b} \quad=$ basal crop coefficient for FAO-56 dual crop coefficient method 


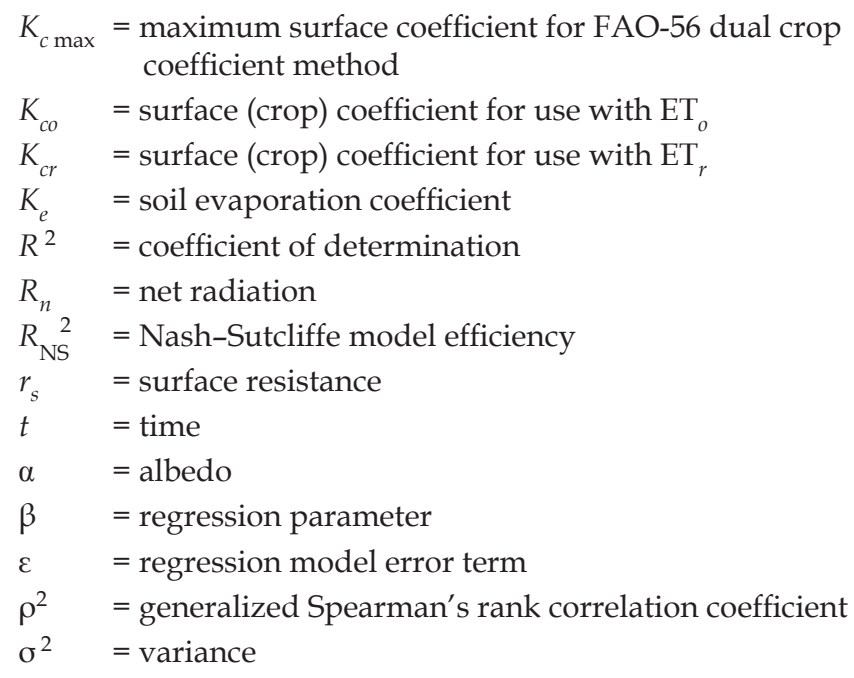

\section{References}

Allen, R. G. (1996). “Nongrowing season evaporation in northern Utah." Proc., North American Water and Environment Congress, ASCE, Reston, Va.

Allen, R. G., Pereira, L. S., Raes, D., and Smith, M. (1998). “Crop evapotranspiration: Guidelines for computing crop water requirements." FAO Irrigation and Drainage Paper No. 56, Rome.

Allen, R. G., Pereira, L. S., Smith, M., Raes, D., and Wright, J. L. (2005a). "FAO-56 dual crop coefficient method for estimating evaporation from soil and application extensions." J. Irrig. Drain. Eng., 131(1), 2-13.

Allen, R. G., Pruitt, W. O., Raes, D., Smith, M., and Pereira, L. S. (2005b). "Estimating evaporation from bare soil and the crop coefficient for the initial period using common soils information." J. Irrig. Drain. Eng., 131(1), 14-23.

American Society of Civil Engineers-Environmental and Water Resources Institute (ASCE-EWRI). (2005). The ASCE standardized reference evapotranspiration equation, R. G. Allen et al., eds., ASCE, Reston, Va.

ASCE. (1993). "Criteria for evaluation of watershed models." J. Irrig. Drain. Eng., 119(3), 429-442.

Hammer, R. R., Ragon, L. G., and Buechle, A. A. (1981). Soil survey of Clay County, Nebraska, Soil Conservation Service and University of Nebraska Conservation and Survey Division, Lincoln, Neb.

Harell, F. E., Jr. (2001). Regression modeling strategies, Springer, New York.
High Plains Regional Climate Center. (2007); http:/ / www.hprcc. unl.edu (November 2007).

Irmak, A., and Irmak, S. (2008). "Reference and crop evapotranspiration in south central Nebraska. II: Measurement and estimation of actual evapotranspiration for corn." J. Irrig. Drain. Eng., 134(6), 700-715.

Irmak, A., Irmak, S., and Martin, D. L. (2008a). “Reference and crop evapotranspiration in south central Nebraska. I: Comparison and analysis of grass and alfalfa-reference evapotranspiration." J. Irrig. Drain. Eng., 134(6), 690-699.

Irmak, S., et al. (2008b). “On the scaling up leaf stomatal resistance to canopy resistance using photosynthetic photon flux density." Agric. Forest Meteorol., 148, 1034-1044.

Irmak, S., Allen, R. G., and Whitty, E. B. (2003). “Daily grass and alfalfa-reference evapotranspiration estimates and alfalfato-grass evapotranspiration ratios in Florida." J. Irrig. Drain. Eng., 129(5), 360-370.

Irmak, S., Howell, T. A., Allen, R. G., Payero, J. O., and Martin., D. L. (2005). “Standardized ASCE-Penman-Monteith: Impact of sum-ofhourly vs. 24-hr-timestep computations at reference weather station sites." Trans. ASAE, 48(3), 1063-1077.

Irmak, S., Irmak, A., Howell, T. A., Martin, D. L., Payero, J. O., and Copeland, K. S. (2008c). "Variability of alfalfa-reference to grass- reference evapotranspiration ratios in growing and dormant seasons." J. Irrig. Drain. Eng., 134(2), 147-159.

Irmak, S., and Mutiibwa., D. (2008). “Dynamics of photosynthetic photon flux density and light extinction coefficient for assessing some radiant energy interactions for maize canopy." Trans. ASABE, 51(5), 1633-1673.

Irmak, S., Payero, J. O., Martin, D. L., Irmak, A., and Howell, T. A. (2006). "Sensitivity analyses and sensitivity coefficients of the standardized ASCE-Penman-Monteith equation to climate variables." J. Irrig. Drain. Eng., 132(6), 564-578.

Nichols, W. E., and Cuenca, R. H. (1993). "Evaluation of the evaporative fraction for parameterization of the surface energy balance." Water Resour. Res., 29(11), 3681-3690.

Prueger, J. H., Hatfield, J. L., and Sauer, T. J. (1998). “Surface energy balance partitioning over rye and oats cover crops in central Iowa." Geotech. Test. J., 53(3), 263-268.

Sauer, T. J., Hatfield, J. L., Prueger, J. H., and Logsdon, S. D. (1998a). "Energy balance of a corn residue-covered field during snowmelt." J. Am. Water Resour. Assoc., 34(6), 1401-1414.

Sauer, T. J., Hatfield, J. L., Prueger, J. H., and Norman, J. M. (1998b). "Surface energy balance of a corn residue-covered field." Agric. Forest Meteorol., 89(3-4), 155-168.

Shelton, D., Smith, J., and Jasa, P. (2000). “Estimating residue cover." Conservation tillage systems and management, 2nd Ed., R. Reeder, ed., MWPS-45, MidWest Plan Service, Ames, Iowa, $35-46$. 